\title{
DIAMONDIFEROUS VOLCANICLASTIC DEBRIS FLOWS OF WAWA, ONTARIO, CANADA
}

\author{
Nathalie Lefebvre ${ }^{1}$, Maya Kopylova ${ }^{1}$, Kevin Kivi ${ }^{2}$, and Robert Barnett ${ }^{3}$ \\ ${ }^{I}$ Earth and Ocean Sciences Department, University of British Columbia, Canada $;{ }^{2}$ Kennecott Canada Exploration Inc.; ${ }^{3}$ \\ R.L. Barnett Geological Consulting, Canada
}

\section{INTRODUCTION}

Historically the majority of diamonds are recovered from Proterozoic to Cenozoic magmatic rocks such as kimberlite, and lamproite, and occasionally from lamprophyre and basalt. An atypical, highly diamondiferous occurrence has recently been discovered in the western section of the Michipicoten greenstone belt, within the Wawa subprovince of the Superior craton (Fig. 1). To date 22,235 stones in $4080.5 \mathrm{~kg}$ have been recovered. The Wawa rocks are unique because they represent a diamondiferous occurrence between 2600 to $2700 \mathrm{Ma}$ in age (2674 \pm 8 Ma, Stott et al., 2002). They have been metamorphosed and deformed, and little evidence of their primary magmatic nature is preserved. The aim of this study is to determine if these rocks are metamorphic equivalents of known diamondiferous deposits or a new, previously unrecognized, deposit type. This question was addressed using field mapping, and petrographic and mineralogical studies of these Archean rocks.

\section{LITHOSTRATIGRAPHY}

Two types of diamond-bearing rocks have been recognized in the Wawa area. Both rock types have been metamorphosed to upper greenschist facies. The data presented below suggests that the rocks had magmatic predecessors that are interpreted to be a polymict volcaniclastic breccia and a lamprophyre. The lamprophyre is younger than the volcaniclastic breccia, as it contains rare fragments of the breccia. Both the lamprophyre and breccia are intercalated with $2700 \mathrm{Ma}$ felsic to intermediate metavolcanics, intermediate to mafic metavolcanics, and mafic intrusive rocks (Fig. 1).

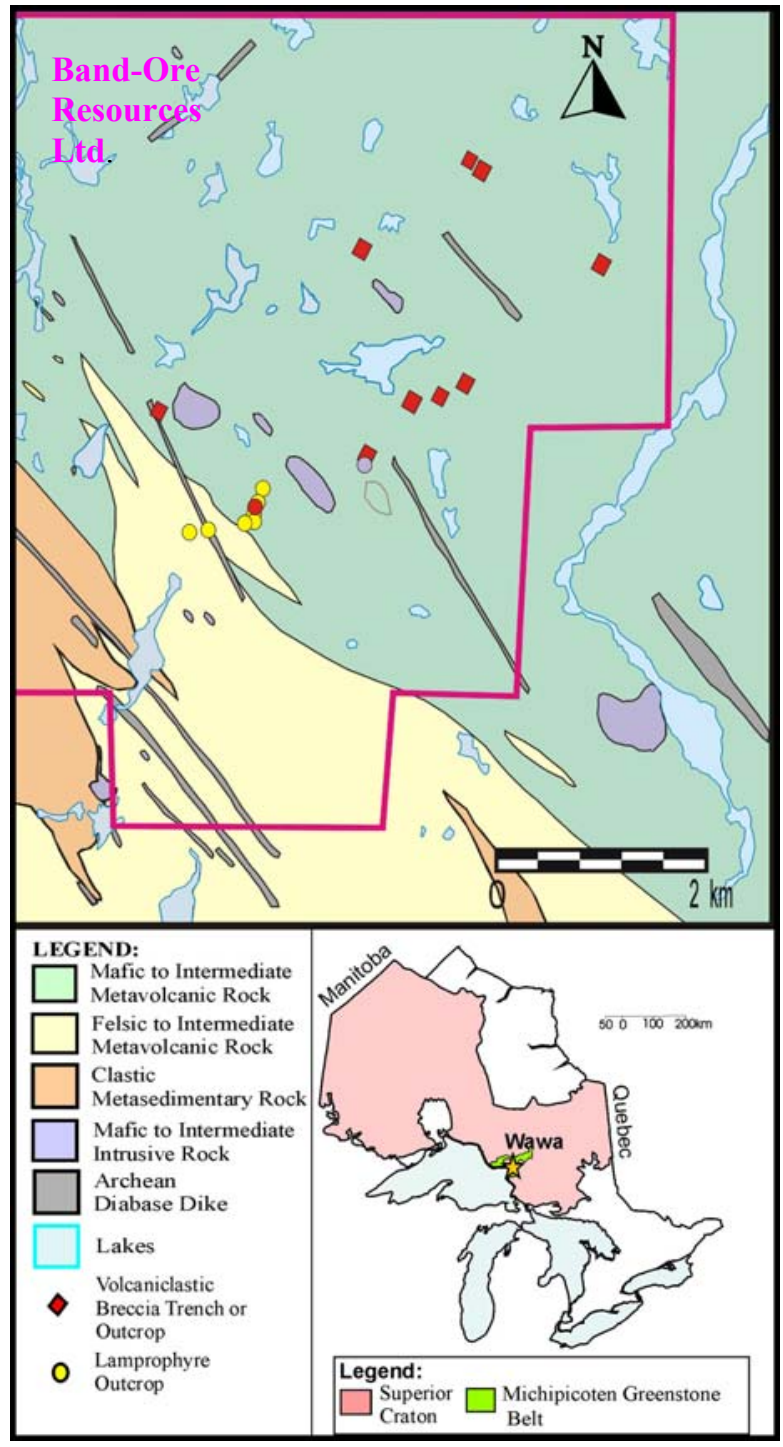

Figure 1: Location of the Wawa diamondiferous rocks within the western section of the Michipicoten Greenstone belt and within the Superior craton. The simplified geology map is modified from Sage (1995). It shows the location of the study area outlined in magenta and the location of the volcaniclastic breccia and lamprophyre occurrences within the greenstone belt rock sequence. 


\section{METAMORPHOSED BRECCIA \\ POLYMICT VOLCANICLASTIC}

The matrix- to clast- supported breccia forms thick ( 60 to $70 \mathrm{~m}$ ) units. It contains dominantly angular, granule to large boulder-sized fragments with a wide variety of mainly igneous lithologies (Fig. 2A), including metamorphosed mantle ultramafic rocks with high $\mathrm{Cr}$ and $\mathrm{Ni}$ content. Irregular and oval shaped, aphanitic fragments and similar aphanitic rinds around lithic fragments (Fig. 2B and C) are present in some breccia areas. These are believed to be juvenile and cored lapilli, and their presence implies incorporation of a pyroclastic component in the breccias. The breccias are interpreted to be volcaniclastic debris flow deposits based on the stratigraphy, the wide range in fragment lithologies, crude bedding (Fig. 2D), poor sorting, and lack of sedimentary structures. The fine-grained matrix of the breccia is comprised of the typical upper greenschist to epidote-amphibolite mineral assemblage for rocks of mafic composition. This assemblage comprises $50-75 \%$ actinolite, $1-20 \%$ epidote, $1-20 \%$ titanite $1-10 \%$ quartz/feldspar, $0-20 \%$ biotite, $0.5-15 \%$ hornblende, and $0-10 \%$ chlorite, with minor calcite, albite, opaques and rutile. At least two foliations are present and are defined by the alignment of acicular and bladed actinolite grains: a shallow NNE dipping foliation (S1) and a weaker S dipping foliation (S2). No obvious igneous textures and minerals have been preserved. Occasional oscillatory zoned hornblende, biotite and and unknown mineral pseudomorphed by epidote are microstructurally pre- to syn-S1 (Fig. 3A). The large, euhedral, oscillatory zoned grains of hornblende are interpreted as possible relict phenocrysts and probably the only primary phase preserved (Fig. 3B). Rare biotite grains, which are euhedral and larger than the matrix biotite, may also be relict phenocrysts.
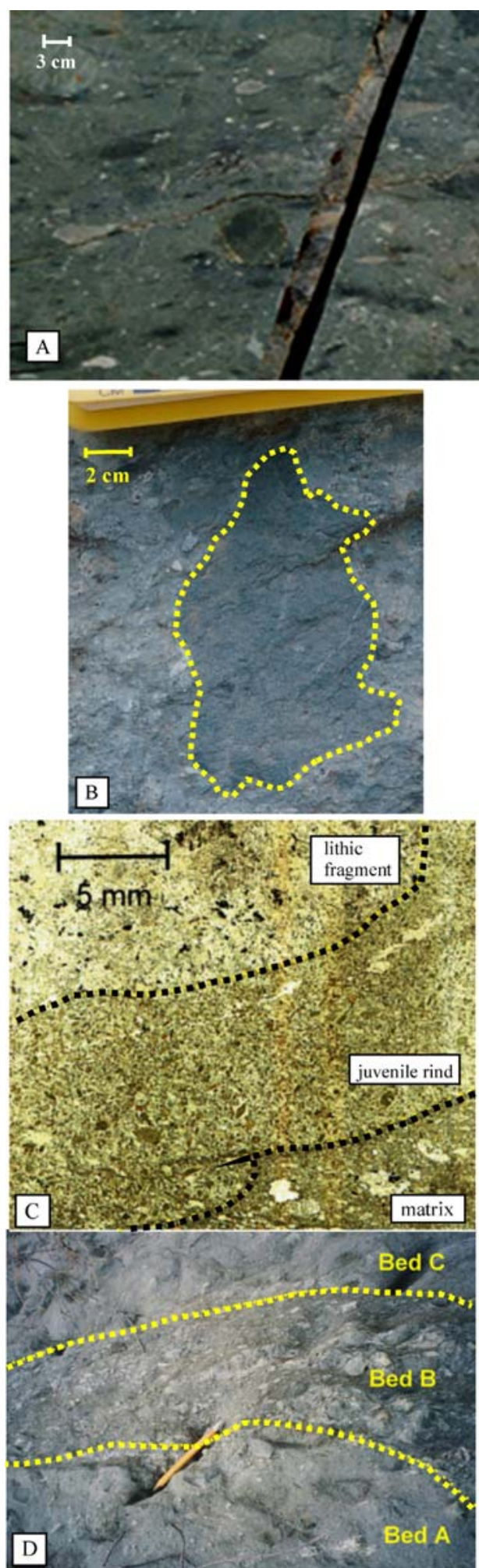

Figure 2: Photographs of volcaniclastic breccia. A. Typical volcaniclastic breccia characterized by poor sorting and wide variety of clast lithologies. B. Juvenile bomb which is outlined in yellow. C. Cored lapilli in thin section. The boundaries of breccia matrix, juvenile rind and lithic fragment are outlined in black. D. Bedding. 


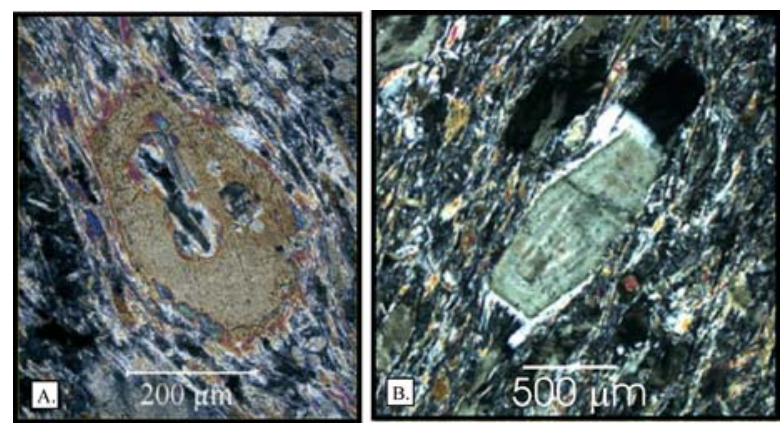

Figure 3: Microphotographs of the volcaniclastic breccia. A. S1 foliation wrapping around a hornblende grain. B. Large grain of oscillatory zoned, pre- to syn-S1 hornblende.
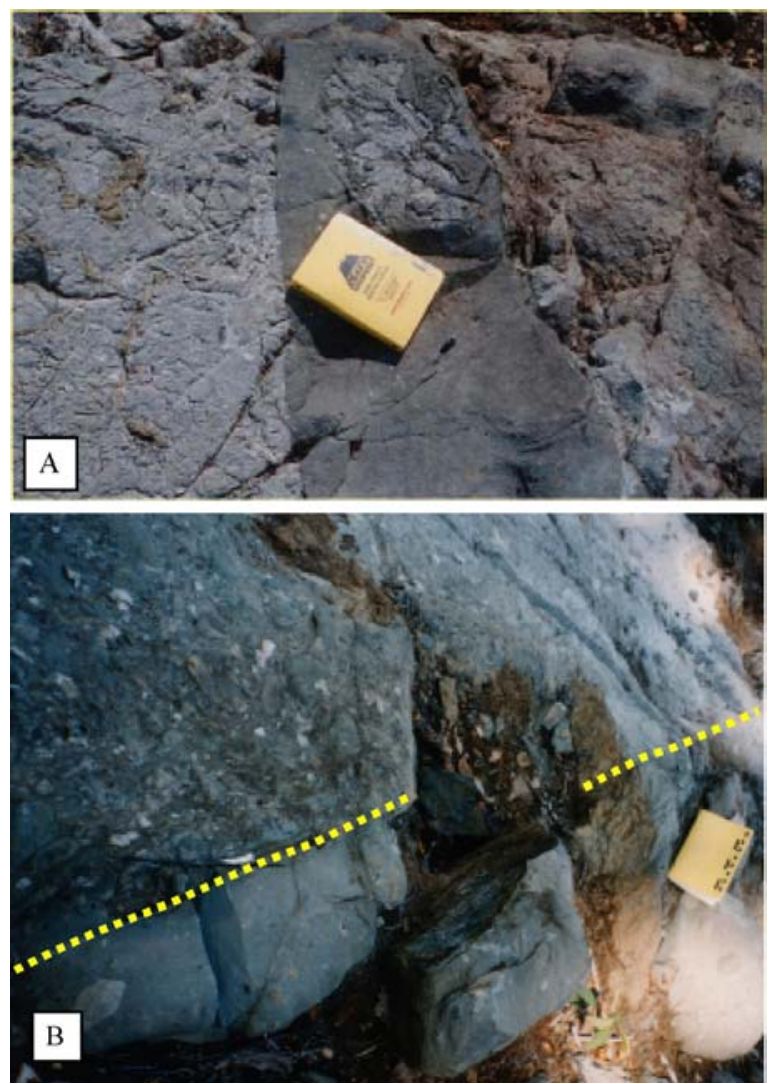

Figure 4: Lamprophyre field photos. A. Lamprophyre dike cross-cutting felsic to intermediate metavolcanic rock. B. Contact between clast-supported volcaniclastic breccia and lamprophyre is outlined in yellow.

\section{METAMORPHOSED LAMPROPHYRIC ROCK}

The lamprophyre commonly occurs as dikes which cross-cut the metavolcanic sequences (Fig. 4A) and the breccia. In other areas the relationship between the lamprophyre and the breccia, and the lamprophyre and metavolcanics is unclear. The lamprophyre overlies these rocks along straight, long, parallel contacts that may be depositional in origin (Fig. 4B). The lamprophyre contains commonly $5-10 \%$ fragments of surrounding country rock, occasional altered ultramafic mantle xenoliths, and rare breccia. It also comprises the upper greenschist mineral assemblage containing $50-80 \%$ actinolite, $1-15 \%$ epidote, $1-10 \%$ titanite, $1-$ $30 \%$ biotite, $1-15 \%$ quartz/feldspar, and $1-7 \%$

hornblende, with minor plagioclase, microcline, chlorite, calcite, opaques, and rutile. The lamprophyre may be weakly foliated as defined by faint alignment of actinolite and biotite grains. Petrographically, it differs from the breccia by 1) overall lower clast abundance; 2) fewer rock types present in the clasts; 3 ) the absence of the juvenile clasts, and 4) the occasional presence of microcline in the matrix.

\section{GEOCHEMISTRY AND MINERALOGY}

\section{BULK ROCK GEOCHEMISTRY}

Whole rock samples of the breccia matrix, juvenile clasts and lamprophyres were analyzed for major and some minor elements. There are no major systematic differences between compositions of the breccia, its juvenile clasts and the lamprophyres. This may be interpreted as a complete obliteration of their primary magmatic compositions by metamorphism, or as a reflection of similar compositions of their magmatic protoliths. The rocks plot in the alkaline to sub-alkaline fields on the $\left(\mathrm{Na}_{2} \mathrm{O}+\mathrm{K}_{2} \mathrm{O}\right)$ vs $\mathrm{SiO}_{2}$ diagram. Major element compositions of the rocks show a better fit to the calc-alkaline lamprophyre and lamproite fields of Rock $(1987,1991)$ than to all other diamondiferous groups of rocks.

\section{Composition of the HoRnBLENDES}

Oscillatory zoned hornblendes (Fig. 3B) were analyzed in the volcaniclastic breccia and the lamprophyre. The pre- to syn- $\mathrm{S} 1$ hornblendes were classified as calcium amphiboles $\left(\mathrm{CaO}\right.$ 6.9-14.9 wt\%, $\mathrm{TiO}_{2}$ 0-3 wt $\%, \mathrm{~K}_{2} \mathrm{O} 0-$ $2.3 \mathrm{wt} \%, \mathrm{Na}_{2} \mathrm{O} 0.4-2.1 \mathrm{wt} \%$ ), specifically tschermakite, pargasite, edenite, and magnesio-hornblende. The hornblende compositions for both rock types are similar; however, pargasitic hornblende is restricted to the lamprophyres, whereas hornblendes of the volcaniclastic breccia are more commonly edenitic. Oscillatory zoned hornblendes from the volcaniclastic breccia showed a common core-to-rim compositional pattern. Magnesio-hornblende cores evolve to edenitic rims or showed oscillations between Mg-hornblende and edenite. From core to rim and within the oscillatory zones, $\mathrm{Na}$ increases, $\mathrm{K}$ decreases slightly, and $\mathrm{Si}$ substitutes for $\mathrm{Al}^{\mathrm{IV}}$.

Magnesio-hornblende, tschermakite, pargasite, and edenites can be found in igneous and lower greenschist 
to amphibolite facies metamorphic rocks. Their compositions, therefore, cannot be ascribed unambiguously to the pre-metamorphic stage of the rock formation. However, the majority of the hornblendes are consistent with a possible magmatic origin based on the $\mathrm{Al}^{\mathrm{VI}}-\mathrm{Si}$, and the $(\mathrm{Ca}+\mathrm{Na}+\mathrm{K})-\mathrm{Si}$ plots (Leake, 1965, 1971). On the $\mathrm{FeO}-\mathrm{SiO}_{2-}$ $\left(\mathrm{Na}_{2} \mathrm{O}+\mathrm{K}_{2} \mathrm{O}\right)$ ternary plots (Wones and Gilbert, 1982), the hornblendes fit within fields of amphiboles in mafic parageneses, as expected from the overall greenschist metamorphic mineral assemblage of the Wawa rocks.

\section{POSSIBLE MAGMATIC PROTOLITH}

Few clues are available to reconstruct the magmatic predecessors of the Wawa diamondiferous rocks and to classify them. Their bulk rock compositions cannot be used, as the rocks have incorporated mantle xenolithic material and may have experienced compositional changes during metamorphism. Reconstruction of the primary magmatic compositions is most likely to be successful if based on petrography and mineral chemistry of the pre- to syn-S1 minerals. These include biotite, hornblende and an unknown mineral pseudomorphed by epidote. Hornblende has the best chance of retaining the relic magmatic compositions because it displays concentric oscillatory zoning that is rarely found in metamorphic rocks (Hoskin and Black, 2000; Schaltegger et al., 1999). Assuming that Mghornblende, tschermakite, edenite and pargasite retained their magmatic compositions, their protoliths were petrographically and chemically close to calcalkaline lamprophyres. These hornblende compositions are not compatible with orangeites and lamproites as their possible magmatic hosts; the latter contain Ti- and K- richterites (Mitchell and Bergman,1991; Mitchell, 1995). Hornblendes found in the Wawa lamprophyre and the volcaniclastic breccia could have crystallized from calc-alkaline lamprophyre, but do not match compositions of amphiboles in alkali and ultramafic lamprophyres (Woolley et al., 1996; Rock, 1991). Larger crystals of epidote may have been pseudomorphed phenocrysts of clinopyroxene, as the epidote is Cr-rich (B. Doyle, Pers. Comm.). Assuming that the modal abundances of the pre- to syn-S1 minerals (1 - 15\% clinopyroxene, $1-5 \%$ biotite, $1-15 \%$ hornblende) reflect the primary magmatic abundances, this calc-alkaline lamprophyre should be called spessartite.

\section{DIAMONDS}

Diamonds are found in the breccias and the lamprophyres. Both contain metamorphosed ultramafic mantle xenoliths identified by their high $\mathrm{Cr}$ and $\mathrm{Ni}$ - content. The presence of these xenoliths and diamonds is evidence for preservation and incorporation of mantle material in the lamprophyric magma.

The diamond population recovered from the polymict volcaniclastic breccia are characterized by their morphology, colour, degree of resorption, and surface features. This diamond population is dominated by microdiamonds. Among 64 macrodiamonds, the majority are colourless (48\%), have non-uniform colour $(30 \%)$, or are yellow (17\%) and overall show very little resorption. They form single crystals and aggregates with predominant octahedral and occasional cubic morphology (Fig. 5). Many of the diamonds have experienced breakage and late etching.

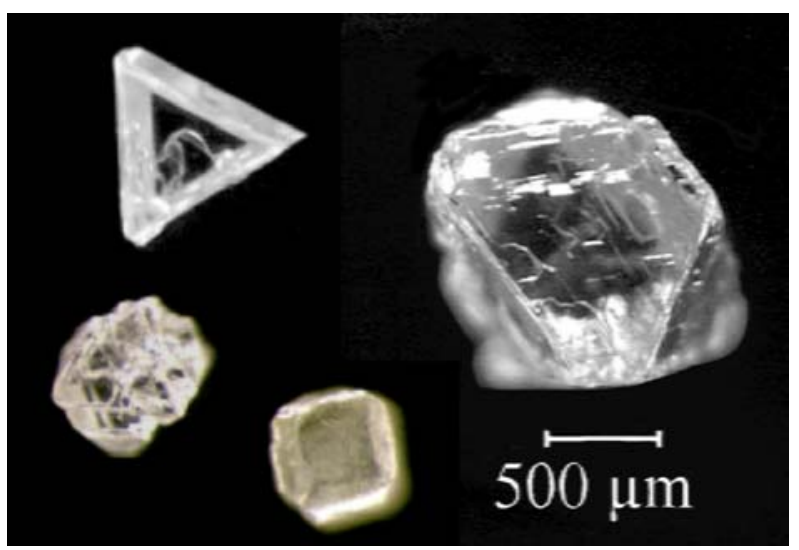

Figure 5: Wawa diamonds recovered from the volcaniclastic breccia. An octahedral aggregate, a cubic crystal, a macle and an octahedral crystal with trigonal and hexagonal pitting.

\section{DISCUSSION}

The two types of diamondiferous rocks from Wawa, Ontario have been interpreted as metamorphosed polymict volcaniclastic breccia and lamprophyre based on field observations, petrographic studies, and mineral chemistry. The matrix of the breccia, the juvenile material and the lamprophyre have similar mineral assemblages, bulk rock compositions and mineral chemistry which suggests they may have formed from a similar type of magma. This primary magma was likely to have calc-alkaline affinity based on the chemistry of the oscillatory zoned, pre- to syn- S1 hornblende. The magma must have originated in the diamond stability field, as it incorporated diamond-bearing mantle material upon its ascent to the surface. It erupted in the Archean to produce volcaniclastic deposits and later also intruded as dikes. A highly explosive eruption style that produces volcaniclastic rocks is not characteristic of lamprophyric magmas that commonly intrude as dykes. Thus, the Wawa diamondiferous rocks could be 
one of few known lamprophyric volcanoes. Other examples have been described in Namibia, New Mexico (Rock, 1991) and Southern Alberta (Kjarsgaard, 1994). The Wawa calc-alkaline lamprophyres belong to a greenstone belt volcanic sequence and formed in a subduction-related tectonic setting. This tectonic setting is distinct from that of all other currently exploited diamond deposits, but has been reported to host diamonds (Barron et al., 1996; Capdevila et al., 1999). Several diamond occurrences in subduction-related magmatic rocks suggest that diamonds may have already formed at earlier stages of subduction, well before its later incorporation in subcratonic eclogites. Lamprophyric volcaniclastic rocks may be considered a potential target for diamond exploration in the future.

\section{ACKNOWLEDGEMENTS}

We are grateful to Band-Ore Resources Ltd. for their permission and financial contribution to map the Wawa diamondiferous rock trenches on their GQ Property, and for generously donating the diamonds for this study. Field work was carried out with the invaluable assistance of B. Duess and D. Smithson. Also we wish to thank B. Doyle, K. Hickey, G. Dipple and M. Raudsepp for their discussions and comments. This research was partly funded by a National Science and Engineering Research Grant. N. Lefebvre has been fully supported through a National Science and Engineering Industrial Post-Graduate Scholarship that has been partly sponsored by Band-Ore Resources Ltd.

\section{REFERENCES}

Barron, L. M., S. R. Lishmund, Oakes, G.M., Barron, B.J., Sutherland, F.L., 1996. Subduction model for the origin of some diamonds in the Phanerozoic of eastern New South Wales. Australian Journal of Earth Sciences 43, 257-267.

Capdeliva, Arndt, R.N., Letendre, J., Sauvage, J-F, 1999., Diamonds in volcaniclastic komatiite from French Guiana. Nature. 399, 456-458.

Hoskin, P.W.O. and L.P. Black 2000., Metamorphic zircon formation by solid-state recrystallization of protolith igneous zircon. Journal of Metamorphic Geology, 18, 423-439.

Kjarsgaard, B.A., 1994. Potassic magmatism in the Milk River area, southern Alberta: petrology and economic potential. In: Interior Plains and Arctic Canada, Geological Survey of Canada, Current Research 1994B, 59-68.

Leake, B.E., 1965. The relationship between tetrahedral aluminium and the maximum possible octahedral aluminium in natural calciferous and subcalciferous amphiboles. Amer. Min. 5, 843-851.

Leake, B.E., 1971. On aluminous and edentic hornblendes. Min. Mag. 38, 389-407.

Mitchell, R.H., Bergman, S.C., 1991. Petrology of Lamproites. New York, N.Y., Plenum Press.

Mitchell, R.H., 1995. Kimberlites, Orangeites, and Related Rocks. New York, Plenum Press.

Rock, N.M.S., 1987. The nature and origin of lamprophyres: an origin. In: Alkaline Igneous Rocks, Fitton and Upton (Eds.), Geological Society Special Publication No.30, 191-226.

Rock, N.M.S., 1991. Lamprophyres. Glasgow, Blackie.

Sage, R.P., 1995. Alteration zones, Michipicoten greenstone belt, central portion; Ontario Geological Survey, Preliminary map P.3322, scale 1:50 000 .

Schaltegger, U., Fanning, M., Gunther, D., Maurin, J.C., Schulmann, K., Gebauer, D., 1999. Growth, annealing and recrystallization of zircon and preservation of monzanite in high-grade metamorphism: conventional and in-situ U-Pb isotope, cathodoluminescence and microchemical evidence. Contrib. Mineral. Petrol. 134, 186-201.

Stott, G.M., Ayer, J.A., Wilson, A.C., Grabowski, G.P.B., 2002. Are the Neoarchean diamond-bearing breccias in the Wawa area related to late-orogenic alkalic and "sanukitoid" intrusions?. Ontario Geological Survey. Open File Report 6100, 9-1 to 9-10.

Wones, D.R., Gilbert, M. C., 1982. Amphiboles in the igneous environment. In: Amphiboles: petrology and experimental phase relations. B.R. Vebelen, P.H. Ribbe (Eds.), Reviews in Mineralogy. 9B, 355-385.

Woolley, A.R., Bergman, S.C., Edgar, A.D., Le Bas, M.J., Mitchell, R.H., Rock, N.M.S., Scott-Smith, B.H., 1996. Classification of lamprophyres, lamproites, kimberlites, and the kalsilitic, melilitic, and leucitic rocks. The Canadian Mineralogist. 34, 175-186.

Contact: NS Lefebvre, 6339 Stores Rd., Department of Earth and Ocean Sciences, University of British Columbia, Vancouver, BC, Canada, V6T 1Z1, E-mail: nlefebvre@eos.ubc.ca 